\title{
ANALISIS EFEKTIVITAS PENGAWASAN INTERN KAS PADA DINAS PERBUHUNGAN KOTA MANADO
}

\author{
Oleh : \\ Demmi P.R.D Buchari \\ Ventje Ilat \\ Inggriani Elim

\begin{abstract}
Fakultas Ekonomi Dan Bisnis Jurusan Akuntansi
Universitas Sam Ratulangi Manado

email : demmibuchari@gmail.com
\end{abstract}

\begin{abstract}
ABSTRAK
Pesatnya teknologi mempengaruhi perkembangan pada setiap perusahaan maupun lembaga, baik swasta dan pemerintah. Khususnya dalam pemerintahan terciptanya akuntabilitas kinerja keuangan merupakan hal mutlak diwujudkan oleh seorang kepaladaerah. Hal tersebut tersirat dalam UU nomor 17 tahun 2003 tentang Keuangan Negara, UU nomor 01 tahun 2004 tentang Perbendaharaan Negara. Penelitian ini dilakukan di Dinas Perhubungan Kota Manado dan membahas pengawasan intern kas. Tujuan dari penelitian adalah mengetahui bagaimana Pengawasan Intern Prosedur Penerimaan dan Pengeluaran, dan Apakah Pengawasan Intern Prosedur Penerimaan dan Pengeluaran Kas yang dilakukan Dinas Perhubungan Kota Manado telah berjalan efektif. Menggunakan metode analisis data deskriptif dengan cara memahami prosedur penerimaan dan pengeluaran kas yang diperoleh dari Dinas Perhubungan Kota Manado. Menggunakan sumber data sekunder Dinas Perhubungan Kota Manado. Hasil dari penelitian ini menunjukkan Dinas Perhubungan Kota Manado telah menjalankan Prosedur Penerimaan dan Pengeluaran kas dengan baik yang sesuai dengan PP No.24 Tahun 2005 dan Permendagri No. 13 Tahun 2006 yaitu mengenai Standar Akuntansi Pemerintahan, dan juga penggunaan dokumen-dokumen dan fungsi otorisasiyang sudah dijalankan sebagaimana mestinya.
\end{abstract}

Kata kunci : analisis, efektivitas, pengawasan

\begin{abstract}
Advancing technology can affect the development of each company or institution, whether private or government. In particular the creation of accountability in government financial performance is an absolute case created by a local chief. Is implicit in the case law (Law) number 17 of 2003 on State Finances, Law number 01 of 2004 on the National Treasury. The research was conducted at the Office of Manado City Relations and discuss the internal control of cash. The purpose of the studywas to determine how the internal controlproceduresrevenues and expenditures and internal control procedures and whether the cash receipts and disbursements made manado city transportation agencies are effective. the analysis method used is the method of analysis of historical data in a way to understand the procedure and the production of cash receipt obtained from the Office of Manado City relationship. use secondary data sources Relations Office of Manado City. Results from this study indicate Relations Office of Manado City has run acceptance procedure and production cash good fit with PP \# 24 in 2005 and No. Permendagri. 13th 2006 that is about Government Accounting Standards, and use of the documents and functions are duly authorized.
\end{abstract}

Keywords : analysis, effectiveness, monitoring 


\section{Latar Belakang}

\section{PENDAHULUAN}

Pemerintah yang besar selalu berhadapan dengan kendala-kendala yang berhubungan dengan pengawasan harta bendanya, khususnya masalah kas, dimana sebagian besar transaksi yang dilakukan perusahaan / lembaga selalu melibatkan kas. Apalagi dengan perkembangan teknologi yang terjadi pada masa sekarang yang memungkinkan masalah penyalahgunaan kas, dengan demikian perusahaan harus lebih aktif dalam melakukan pengawasan kas (Harianto 2010:1).

Mewujudkan akuntabilitas dan tranparansi dalam penyelenggaraan pemerintahan tidak semudah membalikan telapak tangan, diperlukan suatu upaya intensif yang dilakukan secara berkesinambungan. Tahun 2008 Pemerintah telah menerbitkan Peraturan Pemerintah Nomor 60 Tahun 2008 tentang Sistem Pengendalian Intern Pemerintah (SPIP). Perancangan PP tersebut diprakarsai oleh Badan Pengawasan Keuangan dan Pembangunan (BPKP) sebagai pelaksanaan dari pasal 58 ayat (2) Undang-Undang Nomor 1 Tahun 2004 tentang Perbendaharaan Negara. SPIP bertujuan untuk memberikan keyakinan yang memadai bagi tercapainya efektivitas dan efisiensi dalam pencapaian tujuan penyelenggaraan kegiatan pemerintahan, keandalan pelaporan keuangan, pengamanan aset negara, dan ketaatan terhadap peraturan perundang-undangan. Dengan adanya PPSPIP maka setiap menteri/pimpinan lembaga, gubernur, bupati/walikota wajib melakukan pengendalian atas penyelenggaraan kegiatan pemerintahan dengan berpedoman pada SPIP sebagaimana disebutkan dalam pasal 2 ayat (1), dan sekaligus bertanggung jawab atas efektivitas penyelenggaraan sistem pengendalian intern di lingkungan masing-masing.

Pengawasan dapat diartikan sebagai alat untuk mengkoordinasikan aktivitas-aktivitas instansi pemerintahan yang sesuai dengan rencana yang sudah ditetapkan sebelumnya. Salah satu cara untuk melaksanakan pengawasan adalah dengan menyusun sistem pengawasan internal kas yang memadai dan tentunya dapat dipertanggungjawabkan pelaksanaannya dalam mengamankan harta suatu instansi pemerintahan, meningkatkan efisiensi dan mendorong karyawan untuk selalu mematuhi kebijakan-kebijakan yang ditetapkan oleh manajemen sehingga kecurangan dan penyalahgunaan kas dapat diminimalisasi atau bahkan dapat dihindari. Dengan kata lain pengawasan internal kas yang baik didalam instansi perusahaan dapat menunjang keberhasilan setiap keputusan dan peraturan yang telah ditetapkan serta dapat mendukung keberhasilan operasi suatu instansi pemerintahan (Harianto 2010:2).

\section{Tujuan Penelitian}

Tujuan penelitian ini adalah :

1. Untuk mengetahui bagaimana Pengawasan Intern Prosedur Penerimaan dan Pegeluaran Kas Dinas Perhubungan Kota Manado

2. Apakah Pengawasan Intern Prsedur Penerimaan dan Pengeluaran Kas yang dilakukan Dinas Pehubungan Kota Manado telah berjalan efektif

\section{Akuntansi Pemerintahan}

\section{TINJAUAN PUSTAKA}

Akuntansi pemerintahan (governmental accounting) banyak yang menyatakan merupakan terminologi lama. Pada perkembangannya bergeser ke istilah akuntamsi sektor publik. Istilah baru ini didasarkan pada pelebaran wilayah kajian dari akuntansi nirlaba, di mana akuntansi pemerintahan merupakan mekanisme akuntansi memproses transaksi keuangan yang berkaitan dengan pengelolaan negara baik tingkat pusat maupun tingkat daerah. Sementara akuntansi sektor publik meluas pada semua entitas yang bertujuan untuk kesejahteraan masyarakat, misalnya yayasan sosial, lembaga swadaya masyarakat (LSM) dan proyek-proyek kerjasama sektor publik dan swasta (Mursyidi,2009).

Permendagri Nomor 13 Tahun 2006, "akuntansi keuangan daerah adalah semua hak dan kewajiban daerah dalam rangka penyelenggaraan pemerintahan daerag yang dapat dinilai dengan uang, termasuk segala bentuk kekayaan yang berhubungan dengan hak dan kewajiban daerah tersebut ( Halim, dkk, (2010:10).

\section{Perbandingan Organisasi Pemerintah dengan Perusahaan}

Perbedaan akuntansi pemerintahan dengan kondisi akuntansi komersial harus dimulai dengan pemahaman atas karakteristik organisasi pemerintahan. Beberapa karakteristik tersebut adalah sebagai berikut.

1. Pendirian, pembentukan dan kegiatan organisasi pemerintahan bukan dengan tujuan atau bermotif mengejar keuntungan semata-mata. 
2. Organisasi pemerintah demiliki secara kolektif oleh rakyat. Dengan demikian, tidak terdapat saham untuk dimiliki secara pribadi yang dapat diperjualbelikan atau dipertukarkan.

3. Pihak-pihak yang memberikan sumber keuangan kepada organisasi pemerintahan tidak harus menerima imbalan langsung atau proporsional, baik berupa barang, uang, atau jasa.

4. Anggota atau masyarakat, sadar atau tidak, kadang- kadang dipaksa menyetorkan uang atau jasa kepada pemerintah dimana pemerintah akan menggunakan setoran tersebut untuk kepentingan bersama masyarakat.

\section{Sistem Akuntansi Pemerintahan}

Pembaharuan manajemen keuangan daerah di era otonomi daerah ini, ditandai dengan pcrubahan yang sangat mendasar, mulai dari sistem penganggarannya, perbendaharaan sampai kepada pertanggungjawaban laporan keuangannya. Sebelum bergulirnya otonomi daerah, pertanggungjawaban laporan keuangan daerah yang harus disiapkan oleh Pemerintah Daerah hanya herupa Laporan Perhitungan Anggaran dan Nota Perhitungan dan sistem yang digunakan untuk menghasilkan laporan tersebut adalah MAKUDA (Manual Administrasi Keuangan Daerah) yang diberlakukan sejak tahun 1981.

\section{Ciri Khas dan Tujuan Akuntansi Pemerintahan}

Nordiawan, dkk (2007:7:8) menjelaskan dengan beragam karakteristik organisasi pemerintahan, akuntansi pemerintahan berkembang dengan ciri-ciri kas sebagai berikut.

1. Investasi pada aset yang tidak menghasilkan pendapatan, pada umumnya pemerintah dalam memberikan pelayanan kepada masyarakat memerlukan investasi yang besar pada aset yang tidak menghasilkan pendapatan, seperti jalan, jembatan, dan bangunan publik lainnya.

2. Tidak ada pengungkapan laba, tujuan pemerintah adalah memberikan pelayan kepada masyarakat, bukan pencapaian laba. Dalam sektor pemerintahan, tidak terdapat hubungan langsung antara pembayaran pajak oleh masyarakat dengan jasa yang diterima masyarakat. Dengan demikian tidak akan terdapat laporan laba rugi yang mengungkapkan pencapaian sebuah laba.

3. Tidak ada pengungkapan kepemilikan, pemerintah tidak mempunyai kekayaan sendiri sebagaimana perusahaan, dan pemerintah tidak dimiliki oleh individu atau golongan. Dengan demikian, tidak akan terdapat pernyataan atau pengungkapan yang menunjukkan kepemilikan suatu pihak seperti halnya ditunjukkan oleh bagian modal sebuah neraca perusahaan.

4. Penggunaan akuntansi dana, dengan segala karakteristik yang melekat pada organisasinya, akuntansi lebih memandang pemerintah sebagai kesatuan dengan tujuan dan misi tertentu, tidak sebagai sebuah entitas organisasi yang mempunyai kepemilikan. Hal ini memberikan implikasi pada penggunaan persamaan akuntansi yang tidak lagi menggunakan modal pemilik melainkan saldo dana.

\section{Pengertian Efektivitas}

Pengertian efektivitas menurut Schemerhon (1986: 35) dalam Danfar (2009) adalah sebagai berikut.

"Efektivitas adalah pencapaian target output yang diukur dengan cara membandingkan output anggaran atau seharusnya $(\mathrm{OA})$ dengan output realisasi atau sesungguhnya $(\mathrm{OS})$, jika $(\mathrm{OA})>(\mathrm{OS})$ disebut efektif".

\section{Pengawasan Intern}

Sanyoto (2007:259) menyatakan suatu pengawasan intern yang baik dalam perusahaan akan memberikan keuntungan yang sangat berati bagi perusahaan itu sendiri, sebagai berikut ini.

1. Dapat memperkecil kesalahan-kesalahan dalam penyajian data akuntansi, sehingga akan menghasilkan laporan yang benar.

2. Melindungi atau membatasi kemungkinan terjadi kecurangan dan penggelapan-penggelapan.

3. Kegiatan oeganisasi akan dapat dilakukan dengan efisiensi.

4. Mendorong dipatuhinya kebijakan pimpinan.

5. Tidak memerlukan detail audit dalam bentuk pengujian subtantif atas bahan bukti atau data perusahaan yang cukup besar oleh akuntan publik.

\section{Tujuan Pengawasan Intern}

Definisi dan tujuan pengendalian intern, pengendalian intern merupakan tindakan pengendalian dan pengamanan bersifat internal perusahaan. Pengendalian intern lemah dan tidak tepat dapat menimbulkan masalah serius. Informasi yang dihasilkan oleh sistem akuntansi mungkin sekali tidak dapat diandalkan, tidak lengkap, dan mungkin tidak tepat waktu dan sumber daya perusahaan mungkin tidak bermanfaat secara efektif 
dan menjadi rentan terhadap kemungkinan rusak atau hilang. Manajemen perlu memperhatikan memadainya tindakan-tindakan pengendalian dan pengamatan yang membentuk pengendalian intern.

\section{Prinsip Dasar Pegawasan Intern}

Sanyoto (2007:256) mengungkapkan ada beberapa asumsi dasar yang perlu dipahami mengenai pengendalian intern bagi suatu perusahaan sebagai berikut.

1. Sistem pengendalian intern merupakan manajemen responsibility. Bahwa sesungguhnya yang paling berkepentingan terhadap sistem pengendalian intern suatu perusahaan adalah manajemen (lebih tegasnya lagi adalah top manajemen/direksi), karena dengan system pengendalian intern yang baik itulah top manajemen dapat mengharapkan kebijakannya dipatuhi, aktiva atau harta perusahaan dilindungi, dan penyelenggaraan pencatatan berjalan baik.

2. Top manajemen bertanggung jawab menyusun system pengendalian intern tentu saja dilaksanakan oleh para stafnya. Dalam penyusunan team yang akan ditugaskan untuk merancang system pengendalian intern, harus dipilih anggotanya dari para ahli/kompeten, termasuk yang berkaitan dengan teknologi informasi.

3. Sistem pengendalian intern seharusnya bersifat generic, mendasar, dan dapat diterapkan pada tiap perusahaan pada umumnya.

4. Sifat dasar pengendalian intern adalah reasonable assurance, artinya tingkat rancangan yang kita desain adalah yang paling optimal. System pengendalian yang paling baik ialah bukan yang paling maksimal, apalagi harus dipertimbangkan keseimbangan cost benefit-nya.

5. Sistem pengendalian intern mempunyai keterbatasan-keterbatasan atau constraints, misalnya adalah sebaikbaiknya control tetapi kalau para pegawai yang melaksanakannya tidak cakap, atau kolusi maka tujuan pengendalian itu mungkin tidak tercapai.

6. Sistem pengendalian intern harus selalu dan terus menerus dievaluasi, diperbaiki, disesuaikan dengan perkembangan kondisi dan teknologi.

\section{Kas}

Kas adalah komponen aktiva yang paling aktif dan sangat mempengaruhi setiap transaksi yang terjadi. Hal ini dikarenakan setiap transaksi memerlukan suatu dasar pengukuran yaitu kas. Bahkan walaupun perkiraan kas tidak langsung terlibat dalam transaksi tersebut besarnya nilai transaksi tetap diukur dengan kas. Kas adalah aktiva yang tidak produktif. Oleh karena itu kas harus dijaga supaya jumlah kas tidak terlalu besar sehingga tidak ada kas yang menganggur. Disamping itu kas merupaka suatu aktiva yang paling mudah diselewengkan dan digunakan dengan tidak semestinya oleh karyawan karena kas merupakan aktiva yang paling bernilai dibandingkan dengan aktiva lainnya serta paling muda dipindahtangankan (IAI 2002:207).

\section{Prosedur Penerimaan kas}

Dalam kaitannya dengan pendapatan daerah sebagaimana telah berjalan terdapat beberapa ketentuan tambahan yang perlu mendapat perhatian sebagai berikut.

a. Penyetoran uang ke rekening kas umum daerah dianggap sah setelah kuasa BUD menerima nota kredit dari bank yang bertindak sebagai rekening kas umum daerah.

b. Bendahara penerimaan tidak diperbolehkan membuka rekening atas nama pribadi pada bank atau giro pos dengan tujuan pelaksanaan APBD dan tidak diperbolehkan menyuimpan uang, cek atau surat berharga lebih dari 1 hari kerja.

c. Penerimaan daerah yang disetor ke rekening kas umum daerah, dilakukan dengan cara :

1. Disetor oleh pihak ketiga melalui bendahara penerimaan atau bendahara penerimaan pembantu.

2. Disetor langung oleh pihak ketiga ke bank pada rekening kas umum daerah.

3. Disetor pleh pihak ketiga melalui bank lain, badan, lembaga keuangan dan kantor pos.

d. Dokumen yang digunakan didalam prosedur dan penata usaha pajak daerah dan retribusi daerah sebagai berikut.

1. Surat Ketetapan Pajak Daerah (SKP-Daerah)

2. Surat Ketetapan Retribusi Daerah (SKR-Daerah)

3. Surat Tanda Setoran (STS)

4. Surat tanda bkti pembayaran

5. Bukti penerimaan lainnya yang sah

6. Nota kredit 
e. Benda berharga seperti karcis retribusi sebagai tanda bukti pembayaran oleh pihak ketiga kepada bendahara penerimaan diterbitkan dan disahkan oleh pejabat pengelolaan keuangan daerah (Darise 2008:168).

\section{Prosedur Pengeluaran Kas}

Dasar hukum pelaksanaan anggaran pada SKPD sebagai pengguna anggaran adalah DPA SKPD yang btelah disetujui oleh sekertaris daerah dan disahkan pejabat pengelolaan daerah. Persetujuan sekertaris daerah ditandai dengan penandatanganan pada lembar pertama DPA SKPD sedang lembar berikutnya ditandatangani oleh pejabat pengelolaan keuangan daerah. Sebagai langkah pertama dari kegiatan pengekuaran uang dari kas umum daerah atas beban APBD berdasarkan surat penyediaan dana (SPD) atau dokumen lain yang dipersamakan dgn SPD. Berdasarkan SPD yang diterima, bendahara pengeluaran /pejabat pelaksana teknis kegiatan (PPTK) mengajukan SPP kepada pengguna anggaran/kuasa penggua anggaran melalui pejabat penata usaha keuangan (PPK) SKPD.

Dokumen SPP dinyatakan lengkap dan sah, kemudian pengguna anggaran/kuasa pengguna anggaran menerbitkan SPM. Di lain pihak apabila dokumen SPP tidak lengkap atau tidak sah, pengguna anggaran/kuasa menolak menerbitkan SPM. Penyiapan SPM dilakukan oleh PPK SKPD, penandatanganan dilakukan oleh pengguna anggaran/kuasa pengguna anggaran.

SPM yang telah diterbitkan oleh pengguna/kuasa pengguna anggaran diajukan kepada pejabat pengelolaan keuangan daerah untuk penerbitan SP2D.

Dalam rangka pelaksanaan pembayaran sebelum menerbitkan SP2D berkewajiban untuk :

a. Meneliti kelengkapan surat perintah pembayaran yang diterbitkan oleh pengguna anggaran.

b. Menguji kebenaran perhitungan tagihan atas beban APBD yang tercantum dalam perintah pembayaran

c. Menguji ketersediaan dana yang bersangkutan

d. Memerintahkan pencairan dana sebagai dasar pengeluaran daerah dengan menerbitkan SP2D atas SPM yang diterima pengguna anggaran paling lama 2 hari kerja sejak SPM diterima (Darise 2008:169).

\section{Penelitian Terdahulu}

Tabel 1. Penelitian Terdahulu

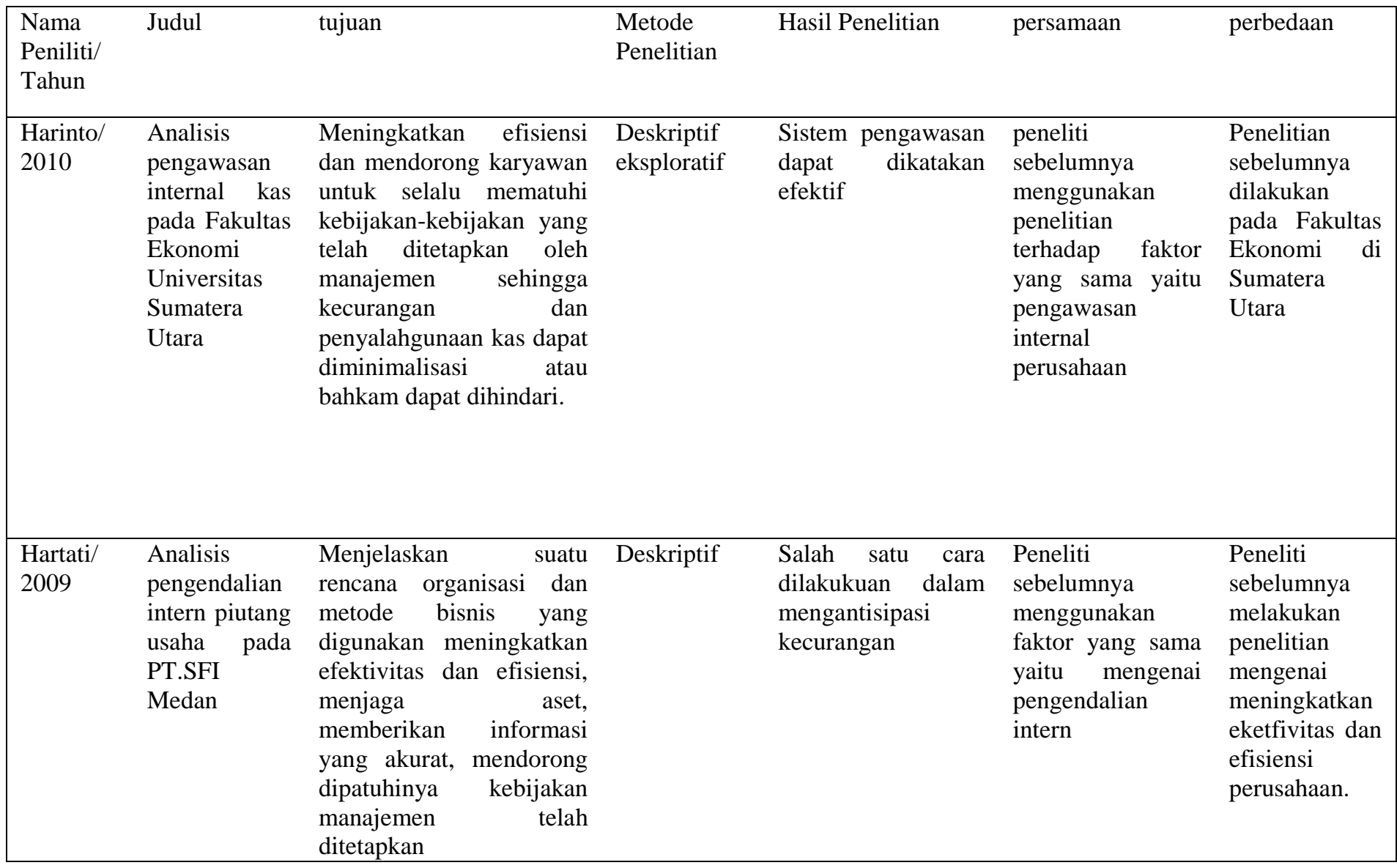




\section{Jenis Penelitian}

\section{METODE PENELITIAN}

Penelitian ini merupakan penelitian deskriptif. Penelitian ini menggambarkan data yang diperoleh dan menganalisis data yang ada. Penelitian deskriptif meliputi penilaian sikap atau pendapat terhadap individu, organisasi, keadaan, ataupun prosedur. Data deskriptif pada umumnya dikumpulkan melali daftar pertanyaan dalam survei, wawancara ataupun observasi(Kuncoro 2009:12).

\section{Tempat dan Waktu Penelitian}

Penelitian ini dilakukan di Dinas Perhubungan Kota Manado yang beralamat di jalan Cereme. Dan waktu penelitian dimulai dari bulan Februari 2013.

\section{Prosedur Penelitian}

Penelitian ini menggunakan tahapan penelitian sebagai berikut :

1. Mengidentifikasi permasalahan yang signifikan untuk dipecahkan melalui metode deskriptif.

2. Merumuskan permasalahan yang jelas dan menentukan tujuan dan manfaat penelitian.

3. Mengumpulkan informasi mengenai gambaran umum perusahaan dan data mengenai analisis efektifivitas pengawasan intern kas pada dinas perhubungan kota manado.

4. Menganalisis efektivitas pengawasan intern kas pada dinas perhubungan.

5. Membuat kesimpulan dan saran bagi dinas perhubungan.

\section{Metode Penelitian}

Salah satu kegiatan dalam penelitian ini adalah merumuskan teknik pengumpulan data sesuai dengan masalah yang diteliti. Agar diperoleh data dan keterangan yang lengkap maka harus menggunakan teknik pengumpulan data yang tepat. Untuk itu teknik yang digunakan dalam penelitian ini adalah studi lapangan, metode yang digunakan untuk mengetahui seberapa jauh kesesuaian antara teori yang digunakan dengan keadaan yang sebenarnya dari objek yang diteliti. Dalam studi lapangan ini penelitian digunakan dengan 3 cara, yaitu :

1. Wawancara langsung, yaitu dengan percakapan langsung serta tanya jawab dengan pihak Dinas Perhubungan pada bagian keuangan.

2. Studi dokumentasi, dilakukan dengan melakukan penelurusan terhadap dokumen-dokumen yang mendukung penelitian.

3. Pengamatan / observasi, yaitu dengan melakukan pengamatan dan kunjungan.

\section{Hasil Penelitian}

\section{HASIL PENELITAN DAN PEMBAHASAN}

Sistem pengawasan internal kas di Dinas Perhubungan Kota Manado dijelaskan dalam penjelasan tersebut. Dijelaskan langkah awal dari bendahara pengeluaran membuat surat permintaan pembayaran dibawa ke pejabat keuangan SKPD untuk diverifikasi kemudian diserahkan kepada PPTK (Pejabat Pelaksana Teknis Kegiatan) untuk diteliti dan diperiksa kemudian ditandatagani. Kemudian bendahara pengeluaran membuat surat perintah membayar untuk diteliti kembali kelengkapan persyaratan berkas setelah dinilai lengkap diajukan kepada kepala dinas untuk ditandatangani. Bendahara pengeluaran membuat dokumen pelengkap atau bukti surat setoran pajak (SSP, daftar bayar), langsung diajukan ke pejabat pelaksana teknis kegiatan (PPTK) untuk ditandatangani kemudian diajukan lagi ke kepala dinas untuk ditandatangani berkas lengkap diajukan lagi ke kepala bagian keuangan pemerintah kota, untuk menerbitkan surat pencairan dana ke bendahara, kemudian berkas tersebut langsung dikirim ke Bank Sulut, untuk pencairan dana.

Dasarnya semua pembayaran yang dilakukan oleh Dinas Perhubungan Kota Manado hanya untuk pembayaran kas yang telah diotorisasi sebelumnya. Dalam proses pembuatan surat permintaan pencairan dana (SP2D) yang akan diserahkan pada bendaraha umum, bendahara harus membuat terlebih dahulu beberapa dokumen seperti surat perintah pembayaran (SPP), surat perintah membayar (SPM) dan beberapa dokumen pendukung.

Pembayaran yang berhubungan dengan pihak ketiga atau suatu pekerjaan yang merupakan hasil dari suatu pelelangan, pembayaran atau pencairannya berdasarkan persentasi hasil dari suatu pekerjaan tersebut, hasil pekerjaan ini pun dapat ditentukan presentasinya adalah berdasarkan penilaian oleh tim yang dibentuk atau ditugaskan oleh Kepala Dinas. 


\section{Sistem Pengawasan Internal Kas di Dinas Perhubungan Kota Manado}

Hery ( 2013 : 159 ) menyatakan pengawasan internal adalah seperangkat kebijakan dan proses untuk melindungi aset atau kekayaan dari segala bentuktindakan penyalahgunaan, menjamin tersedianya informasi akuntansi perusahaan yang akurat, serta memastikan bahwa semua ketentuan (peraturan) hukum / undangundang serta kebijakan manajemen telah dipatuhi atau dijalankan sebagaimana mestinya oleh seluruh karyawan perusahaan. Ketentuan yang dimaksud dalam pengertian tersebut meliputi peraturan dibidang perpajakan, pasar modal, hukum bisnis, undang-undang anti korupsi, dan terlebih khusus ketentuan dalam kepemerintahan.

Aspek perencanaan dan pengawasan internal terhadap kas harus mendapat perhatian yang serius oleh instansi, hal ini dapat dilihat dari sifat-sifat kas dimana setiap pengawasan internal terhadap kas yang harus diciptakan untuk melindungi keamanan dan meningkatkan efektifitas dan efesiensi pengguna manajemen.

\section{Prosedur Penerimaan Kas Dinas Perhubungan Kota Manado}

Prosedur penerimaan kas dalam instansi pemerintahan perlu dirancang sedemikian rupa sehingga kemungkinan tidak tercatat atau tidak diterimanya kas yang seharusnya diterima dapat diminimalkan. Prosedur penerimaan kas perlu memperhatikan hal-hal sebagai berikut :

a. Terdapat pemisahan tugas antara yang menyimpan, menerima dan yang mencatat penerimaan kas.

b. Setiap penerimaan kas langsung disetor kepada bank bagaimana adanya.

Dinas Perhubungan Kota Manado Bendahara Penerimaan wajib menyelenggarakan penatausahaan terhadap seluruh penerimaan dan penyetoran yang menjadi tanggungjawabnya. Ini sudah sesuai dengan Permendagri 13/2006 pasal 187 - 189 mengatur tata cara pelaksanaan penerimaan daerah yang dikelola oleh Bendahara Penerimaan. Penerimaan Kas pada Dinas Perhubungan Kota Manado bersumber dari Peraturan Daerah (Perda) Meliputi :

a) Retribusi Tepi Jalan Umum (TJU)

b) Retribusi Pengujian Kendaraan Bermotor (PKB)

c) Retribusi Jasa Ketata Usahaan (TU)

d) Retribusi Terminal Bulanan

e) Retribusi Parkir

f) Retribusi Ijin

g) Retribusi Karcis.

Bendahara Penerimaan bertanggungjawab pada Kepala SKPD atas pengelolaan uang yang menjadi tugasnya secara administratif, namun secara fungsional Bendahara Penerimaan SKPD bertanggung jawab pada PPKD.

Prosedur penerimaan kas yang dilakukan Dinas Perhubungan Kota Manado menurut penulis sudah cukup memadai, hal ini ditandai karena :

1) Adanya tanggungjawab pengelolaan dan pengawasan kas

2) Semua surat-surat masuk dibukukan dengan pengawasan yang cukup

3) Dibuatnya catatan oleh yang membukukan surat tentang uang yang diterima dari siapa, jumlahnya, dan untuk siapa

4) Setiap penerimaan menggunakan bukti-bukti penerimaan

5) Bukti setoran kas dicocokkan dengan buku kas dan lembaran buku bank

6) Pengunaan bukti-bukti yang telah dirancang dengan baik, dimana bukti-bukti tersebut berguna untuk membuktikan terjadinya transaksi atau penerimaan kas yang telah dirancang sedemikian rupa.

7) Penyimpanan bukti-bukti pendukung dalam tempat yang rapi dan berurutan.

\section{Prosedur Pengeluaran Kas Dinas Perhubungan Kota Manado}

Setiap pengeluaran yang dilakukan oleh Dinas Perhubungan Kota Manado harus mendapatkan persetujuan dari pejabat yang berwenang. Prosedur pengeluaran kas pada Dinas Perhubungan Kota Manado yang meliputi serangkaian proses baik manual maupun terkomputerisasi mulai dari pencatatan, penggolongan, peringkasan, transaksi atau kejadian keuangan serta pelaporan keuangan dalam rangka pertanggungjawaban.

Adapun prosedur pengeluaran kas secara rinci yang dilaksanakan oleh Dinas Perhubungan Kota Manado adalah sebagai berikut :

1) Menerima berkas tagihan pembayaran

2) Melampirkan dokumen pendukung pengeluaran uang

3) Membuat bukti pengeluaran kas dan mencetaknya

4) Memaraf/ meminta tanda tangan pengesahan persetujuan pembayaran di bukti pengeluaran kas

5) Meminta pengesahan pejabat yang berhak menyetujui pembayaran di bukti pengeluaran kas 
6) Mencatatkan segala jenis transaksi pegeluaran kedalam buku kas/buku laporan

7) Melaporkan segala jenis pengeluaran Dinas Perhubungan Kota Manado kepada Kepala Dinas Perhubungan Kota Manado setiap bulannya

8) Jika terdapat dana yang tidak sempat digunakan berdasarkan program kerja satuan kerja perangkat daerah (SKPD) pada tahun berjalan maka dana tersebut tetap berada di APBD induk(Pemkot Manado).

Prosedur pengeluaran kas pada Dinas Perhubungan Kota Manado berdasarkan penjelasan diatas diterapkan dengan baik. Penerapan pengeluaran kas telah dilakukan secara sistematis, dimulai dari bendahara kemudian diotorisasi oleh SKPD salah satunya Kepala Dinas Perhubungan Kota Manado selaku penggunaan anggaran. Pada Dinas Perhubungan kota Manado terdapat berbagai pengeluaran kas seperti :

a) Belanja Kesejahteraan Pegawai :

- Gaji dan Pendapatan Lain yang Sah

b) Belanja Operasional Kantor :

- ATK

- Peralatan Kantor

c) Belanja Pembangunan :

- Dilaksanakan berdasarkan rencana strategis dan rencana kerja SKPD

d) Belanja pemeliharaan :

- pemeliharaan perabot/ inventaris

- pemeliharaan kendaraan operasional

- Pemeliharaan investasi dan peralatan/perabot penunjang

- pemeliharaan gedung, Instalasi air dan listrik

e) Belanja perjalanan

- Melaksanakan perjalanan dinas luar

\section{DAFTAR PUSTAKA}

Danfar .2009. Definisi/Pengertian efektivitas .DF. Bandung.

http://dansite.wordpress.com/2009/03/28/pengertian-efektifitas/Diakses Mey, 17, 2013

Darise, Nurlan. 2008. Akuntansi Keuangan Daerah. PT.Indeks. Jakarta.

Halim Abdul., Yanuar., I Wayan. 2010. Sistem Akuntansi Sektor Publik. UPP STIM YKPN. Yogyakarta.

Harianto. 2010. Analisis Pengawasan Internal Kas Pada Fakultas Ekonomi Sumatera Utara. Skripsi. Universitas Sumatera Utara. Medan.

Hartati, Dian. 2009. Analisis Penendalian Intern Piutang Usaha Pada PT.SFI Medan. Skripsi.Universitas Sumatera Utara. Medan.

Hery. 2013. Akuntansi Dasar 1 \& 2. PT Gramedia Widiarsarana Indonesia. Jakarta.

Ikatan Akuntan Indonesia. 2002. Standar Akuntansi Keuangan. Salemba Empat. Jakarta.

Kuncoro, Mudrajad. 2009. Metode Riset Untuk Bisnis dan Ekonomi. Edisi Ketiga. Erlangga. Jakarta.

Mursyidi.2009. Akuntansi Pemerintahan di Indonesia. PT Refika Aditama.Bandung.

Nordiawan., Putra., Rahmawati. 2007. Akuntansi Pemerintahan. Salemba Empat. Jakarta.

Republik Indonesia, PP Nomor 60 Tahun 2008 tentang . "Sistem Pengendalian Intern Pemerintah". Jakarta. , UU Nomor 1 Tahun 2004 tentang . "Perbendaharaan Negara”. Jakarta.

Sanyoto. 2007. Audit Sistem Informasi + Pendekatan CobIT. Edisi Revisi.Mitra Wacana Media. Jakarta. 